Univerzitet u Beogradu
Poljoprivredni fakultet
Institut za poljoprivrednu tehniku
Naučni časopis
POLJOPRIVREDNA TEHNIKA
Godina XLIV
Broj 2, 2019.
Strane: $13-22$
Faculty of Agriculture

UDK: 631.3 .

\title{
AUTOMATIZATION AND DIGITALIZATION IN AGRICULTURE
}

\author{
Miran Lakota*1 ${ }^{* 1}$ Denis Stajnko, Peter Vindiš, Peter Berk, \\ Damijan Kelc, Jurij Rakun \\ University in Maribor, Faculty of Agriculture and Life Sciences, \\ Pivola 10, 2311 Hoče, R. Slovenia
}

Summary. The fourth industrial revolution, which has begun couple of years ago, covers not only "smart" and interconnected machines and systems. It also coincides with further discoveries in various areas, from determining the genome sequence to nanotechnology and from renewable sources to quantum computing. The correlation between these technologies and their interaction in the physical, digital and biological field is what makes the fourth industrial revolution significantly different from the previous ones. The events should be faster, more extensive and radical, which will require the transformation of entire systems through (and within) countries, businesses, industries and society as a whole. We are already talking about switching from financing innovative projects to Comprehensive Innovation Ecosystems (AKIS).

The paper describes some important research work from the field of automatization and digitalization of Slovenian agriculture.

Key words: precision farming, smart farming, agricultural robotics.

\section{INTRODUCTION - PRECISION FARMING}

If we want Slovenian agriculture to become more competitive, we need to introduce modern agricultural technologies into our agricultural environment. Modern technology includes satellite navigation, which is intensively used in neighbour developed countries.

*Kontakt autor. E-mail adresa: miran.lakota@um.si 
The main factors in precision agriculture represent precise guidance, precise sowing, fertilizing and spraying. And with that we get a better realization of plant production. The use of precision agriculture technologies allows us to plan better and analyse the working procedures. In foreign literature there is a lot of researches on this topic. The structure of land in agri - developed countries is completely different than in Slovenia, and the use of RTK (Real Time Kinematic) navigation comes to a different perspective than on our fragmented land. In the task we want to check the actual saving of time and fuel, which consequently influences the reduction of variable production costs.

Faculty of Agriculture and Life Sciences made some very interesting field navigation experiment (Vajda, 2018). In order to save time and money, we have tested various ways of turning the tractor enabled by RTK technology. The purpose is also to determine the human accuracy of driving the tractor in the field and compare it with the use of RTK precision $( \pm 2 \mathrm{~cm})$. We used tractor Fendt 828 , which was equipped with the RTK navigation system.

We compared how much fuel and time we saved, and the width of overlap using manual driving. The experiment was conducted on two areas of land size of $172 \times 58$ meters, and the two working machines wide 3 and 6 meters. When the experiment was done, we saved $15,7 \%$ of the time and $8,66 \%$ of the fuel on a working machine of 3 meters wide, and $12,6 \%$ of the time and $8,28 \%$ of the fuel on a working machine of 6 meters wide. The width of the overlap represents $10 \%$ of the working width of the machine, and with the method of turning, which RTK navigation allows, we saved additional time.

Our findings are consistent with the Hege research [14]. He demonstrated the positive characteristics of RTK autonomous tractor driving in mechanical weed control in the production of onions and spinach.

A reference or base station is indispensable to determine the accuracy of the position less than one meter. This could be your own mobile or permanent reference station owned by an operator and used by several users. A permanently operating reference station is permanently located where there are no disturbing factors, such as large reflecting surfaces or radio transmitters. Since the coordinates of the reference station are precisely determined, the receiver can determine observation corrections from observations and known satellite positions. Through the communication channels (GSM, UMTS, NTRIP), the reference station in the form of standardized records sends such data to mobile receivers in the field, in our case on the tractor. Using the obtained data, the receiver, together with its data from observations or corrections of the reference receiver, determines its precise position in real time. The receiver determines its position by measuring the distances to satellites in the universe, creating a replica of the signal it receives from the satellite, and comparing it with the signal generated in the receiver. Because the signal on the Earth is very weak, special signalling is required. The locallydetermined signal receiver delays so long that the cross-fermentation function reaches full alignment with the source signal. Signal is ready for further processing. The receiver decodes the position of satellites. The precise position of the receiver is determined by measuring the distances of the four satellites. The position is determined by the method of the smallest squares between pseudo-satellite distances. More available satellites we have, the better and more precise is the quality of locating the position (GNSS, 2018).

In Slovenian only general theoretical information literature dominates. And that is because this type of technology in Slovenia is new and investment is expensive. 
Furthermore, the practical data is still too small for the technology to expand. Most information can be found on the websites of authorized dealers or importers. One such website is Geoservis d.o.o., where we can obtain a sufficient amount of data on the operation and usability of GPS in agriculture [7].

The method of capturing spatial data was first described at the University in Maribor. It was described how to use GPS technology and GPS systems to accurately determine the position in the space, measure the surfaces, ranges and paths, and simultaneously monitor agricultural machines in work tasks. It also provides information on GPS operation, signals, faults, measuring instruments and software [26 ].

The Global Information System (GPS) was very detailed described [14]. He described in detail the composition of GPS, its purpose, accuracy and mistakes. He also devoted much attention to the description of Geographic Information Systems. In the task they monitored the working procedure of ploughing and recorded satellite data with data that were later processed and used for precise calculation of the costs of ploughing. With the help of evidence, a working hypothesis was confirmed that with the aid of the GPS system, we can more accurately assess the costs of ploughing in comparison with the simulation model.

Different GPS systems were compared among each other, differing primarily in their ability to control precision. In the first treatment, a classic manual drive was compared, in the second manual drive in combination with GPS guidance, the third was autonomous driving, and in the last, fourth, autonomous driving with RTK system. The difference between the stated accuracy indicated by the manufacturers and the actual measured accuracy was compared in one experiment in Germany. At first and second treatment, the actual accuracy was worse than stated, namely, the accuracy was indicated for a manual run of $20 \mathrm{~cm}$ and the actual one was $22 \mathrm{~cm}$.

In the second treatment, the accuracy was $10 \mathrm{~cm}$ and the actual one was $12 \mathrm{~cm}$. For the following two systems, the actual accuracy was better than indicated. In the autonomous run without RTK, the accuracy was $5 \mathrm{~cm}$, the actual $3.5 \mathrm{~cm}$, and the RTK 2 $\mathrm{cm}$ and the actual $1.2 \mathrm{~cm}$. In the continuation of this research, the productivity of automatic and manual driving was demonstrated, where productivity was increased by about $8 \%$ in automatic driving, which is 0.5 ha per hour [22].

At the Universität für Bodenkultur in Austria was made interesting study. Three different systems were used to guide the tractor: manual driving, manual GPS-assisted driving, and automatic driving system. With the working width of $15 \mathrm{~m}$ and $3 \mathrm{~m}$, the actual width of the working machine was compared. For a working width of $15 \mathrm{~m}$, the actual working width of the hand-held vehicle was $14.29 \mathrm{~m}$, for GPS assistance and manual driving $14.92 \mathrm{~m}$, and for automatic driving $14.91 \mathrm{~m}$. At a working width of $3 \mathrm{~m}$, the actual working width of the manual drive was $2,775 \mathrm{~m}$, and for GPS assistance and automatic driving 2,906 $\mathrm{m}$. Researchers studied the time needed to process parcels in the size of 3,186 ha. A hand-guided ride was compared to each other, where 29 passes were required to process the plot and 39.38 minutes, of which turning time was 8.4 minutes.

With the help of the GPS system and the ring ride, 28 passages were needed, and 34.12 minutes and a turning time of 4.77 minutes. In automatic driving, 28 passes were needed. 36.05 minutes and 6.02 minutes for turning. For manual driving, the average turning time was 13.39 seconds, while using the GPS system was significantly shorter. 13.38 seconds were used on average for the autonomous driving system and 10.61 seconds for the manual hand-held GPS system. 
Differences in the turning time between the GPS systems were separated due to the longest distance travelled in autonomous driving.

As a matter of interest, at the end of this study, it was stated that with the help of the GPS system, in addition to working area of $5 \mathrm{~m}$, work surface of up to 9 ha can be processed within 12 hours. [16 ].

Lopez [19], showed the savings in manual drive and RTK system in crop production. The savings in the production of silage maize with the GPS system is around $13 € /$ ha, $22 € /$ ha of sugarcane, $22 € /$ ha of sugar beet and $23 € /$ ha for cereals. The highest hectare savings, $61 € /$ ha, was in the production of potatoes. They also showed average hectare savings in all the aforementioned crops, except for potatoes. Using an accuracy of $0.30 \mathrm{~m}$, we can save $4-5 € /$ ha, with an accuracy of $0.15 \mathrm{~m} \mathrm{9-12} € /$ ha and using the RTK system $20-23 € /$ ha.

The Slovenian national network that goes by the name SIGNAL is the GNSS (Global Navigation Satellite System) network, which is made up of 16 uniformly distributed permanent stations throughout the country. The stations are arranged in such a way that the distance between them is less than $70 \mathrm{~km}$, while the borders of the country complement the stations of the neighbouring countries (5 Austrian, 6 Croatian and 1 Hungarian). Network operation of the SIGNAL is provided by the GNSS Service under the auspices of the National Geodetic Authority at the Geodetic Institute of Slovenia. Access to network data Signal is also possible through the DGPS service provided by Telekom Slovenia. In this way, we can access RTK data via the GSM (Global System for Mobile communications) network where the user needs a GSM-modem connected to a mobile server (Ministry of Environment and Space, [20]).

Geoservis d.o.o. Slovenia is the main manager of permanent GNSS stations (Figure 1), where besides own stations, they also take care of partner stations. In Slovenia there are 7 permanent stations, and 4 additional permanent stations will be installed (GNSS, [7]).



Figure 1: Map stations of the company Geoservis, d.o.o. 


\section{SMART AGRICULTURE}

The spectral composition of light reflected from vegetation depends on the condition of vegetation (plant height and canopy density, nutrient supply, water availability, damage due to pests or mechanical factors). This, theoretically, allows a non-destructive evaluation of the physiological and structural condition of the vegetation and to forecast crop yield. Eler\&Co present in his study the potential and limitations of multispectral measurements in three field experiments, where relatively simple and less precise measures (vegetation index) to assess the vegetation condition were used. Correlation of vegetation indices with agronomical relevant vegetation parameters was the highest for the grassland experiment with $r=0.67$ between normalized difference vegetation index (NDVI) and yield.

For maize irrigation experiment, he found significant differences between irrigated and non-irrigated area, but it was difficult to estimate the contribution of higher leaf area index and higher concentration of chlorophyll in irrigated areas to these differences. The vegetation index was the lowest in the experiment with winter barley, where only minor correlations with the physiological status of the crop were found, however some varietyspecific reflectance of spectra and their interaction with $\mathrm{N}$ side dressing was detected during vegetative development [4].

Data acquisition with high resolution multispectral aerial survey in agriculture is increasingly gaining ground.

Multispectral aerial photography makes it possible to get enough objective and, above all, up-to-date documents containing information for further use and transition to precise farming. With the obtained data, which we record with the unmanageable. It is possible to provide aircraft with access to information on production conditions, development and real-time healthcare, allowing timely and appropriate response to the actual situation in the fields [2].

Unmanned aerial systems and related new systems for more precision farming are becoming standard in modern food production. Newer technologies allow faster monitoring and precise plant stress control, soil quality and more accurate assessment of vegetation of cultivated plants. Right interpretation results of high resolution multispectral aerial photography present basis for more precise farming. In order to follow the trend of modern production technologies introduction, the Agricultural Institute of Slovenia purchased unmanned aerial systems with a multispectral camera adapted for agricultural use. The first experimental year with new research equipment showed, enormous potential for further development and research in all agricultural fields Such equipment allows acquiring new and different kind of data which enable better understanding of plant response to various stressful circumstances (drought, nutrition, weeds), which will allow easier transition into precision farming [6].

Satellite images with better temporal and spatial resolution are allowing significant progress in the introduction of systems for the timely detection of drought and mitigation of its effects in agriculture. For greater reliability of satellite images interpretation in the initial stage the knowledge of soil water and its spatial variability is necessary. The experiment by Pintar\&Co was made at four locations in Prekmurje area, further divided into four plots of $20 \mathrm{~m} \mathrm{x} 20 \mathrm{~m}$ ten repetitive measurements of soil - water content in the nine time periods in 2016 were made. The measurements were carried out using a portable TDR probe TRIM FM-1. 
Variability of measurements within individual plots and between the plots was very similar. The coefficient of variation has reached a value between 0.1 and $0.7 \%$. Variations in the water content between the plots at a single location were statistically significant in several dates, but only a few have been relevant and reached a value of 5 to 10 vol. \%. The amount of water in the soil at the time was as a rule up to 25 vol. \%. Due to the low variability, in the following experiment we can reduce the sampling from the current ten to five or six and four or five on the heavy and on light soils, respectively [21].

On the Faculty of Agriculture and Life Sciences, Department for Biosystems Engineering the main research work in last years was made in the field of autonomous robots in agriculture and specially in the field of machine vision and autonomous orientation in space. One of the goals of this work was to investigate the possibility of using two non-costly 2D LIDAR scanners to reconstruct a 3D scene, instead of using a more expensive multi-channel sensor, by applying an alternative SLAM approach. To test the approach a small field robot was fitted with two 2D sensors and the tests were conducted in indoor as well as outdoor environment.

An accurate 3D model of an outdoor scene can be used in many different scenarios of precision agriculture, for instance to analyse the silhouette of a tree crown canopy for precision spraying, to count fruit for fruit yield prediction or to simply navigate a vehicle between the plant rows. Instead of using stereovision, limited by the problems of different light intensities, or by using expensive multi-channel 3D range finder (LIDAR scanner), limited by the number of channels, this work investigates the possibility of using two single channel LIDAR scanners mounted on a small robot to allow a real-time 3D object reconstruction of the robot environment. The approach used readings captured by two LIDAR scanners, SICK LMS111 and SICK TiM310, where the first one was scanning horizontally and the second one vertically. In order to correctly map the 3D points of the readings from the vertical sensor into a 3D space, a custom SLAM algorithm based on image registration techniques was used to calculate the new positions of the robot. The approach was tested in an indoor and outdoor environment, proving its accuracy with an error rate of $0.02 \mathrm{~m} \pm 0.02 \mathrm{~m}$ for vertical and $-0.01 \mathrm{~m} \pm 0.13 \mathrm{~m}$ for the horizontal plane [18].


Figure 2: Indoor environment - a corridor. The left image depicts a real scene, while image in the centre and on the right depict their representation in $3 D$ space 

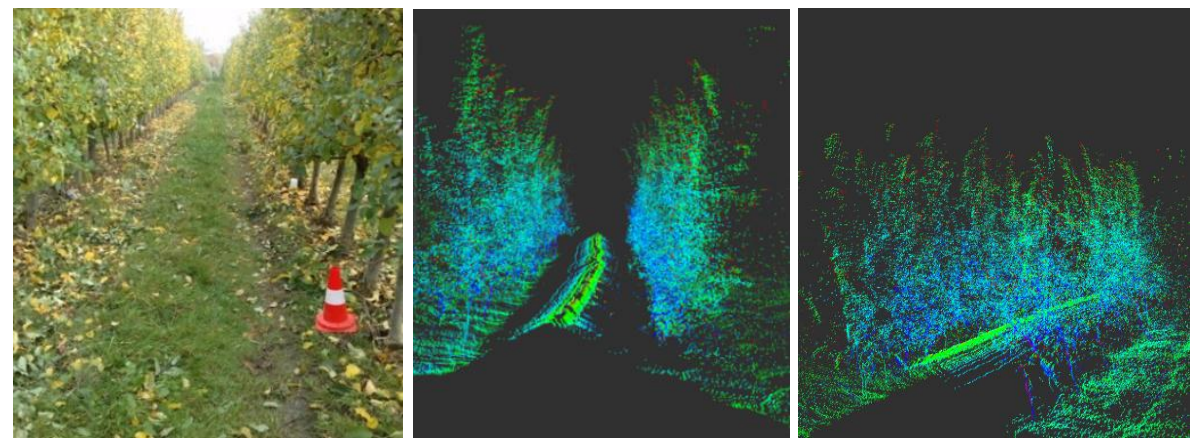

Figure 3: Outdoor environment - apple orchard. The left image depicts a real image, while in the centre and on the right, it shows their representation $3 D$ reconstruction

A 3D map of objects of an environment is useful in many issues of precision agriculture. For instance, it could be used to localise a robot on the field, to prevent it from bumping into obstacles or to plan a trajectory the robot would take to reach its destination [23]. Next, a 3D model could be used to get information about the plant development [5], to evaluate the shape / density of a tree silhouette for precision spraying application [27]. And finally, a 3D model could even be used to pick fruits [3], to measure the size of the trees [4] or to distinguish weed from maize plants [1].

To make an autonomous filed robot it has to include all necessary sensors and logic in order to localise itself, to build a map of the environment and to possibly plan a path it would take to move to a new position. The environment sensing step can be accomplished by using simple ultrasonic or infra-red sensors that produce trivial readings, but if we want to get a more accurate results, more complex sensors should be used, such as cameras, depth cameras, or single/multi-channel LIDAR scanners that produce more detailed results.

Some limitations can be overlooked if we know that the robot will only have to avoid obstacles that are on the ground, where a simple 2D LIDAR can be used to drive between them. The problem is more complex environment, where parts of the objects hang and obstruct the robot. In these cases, it is necessary to build a 3D model of the scene. An example of such approach was described by Ben-Tzvi et al., 2010., where two cameras were used to calculate a depth information by analysing corresponding pixel pairs. The work from Jung et al. [13] is based on the use of digital camera and a projector that emits structured light on to the target and depth information is recorded by measuring the intensity of the reflected light. The closer the object is, the bright the colour and vice versa. The sensors with the highest prices at the moment are 3D LIDAR scanners [23]. They used laser light to measure the distance from the scanner to a point of the scene. In comparison to the ordinary 2D models, the 3D version has multiple channels. This means they take measurements on different planes, but are limited with the number of channels, for instance 16, 32 or 64 .

If a 3D LIDAR scanner is used on a field robot it would make possible for such a robot to sense the environment and navigate between the obstacles [23] . It would be able to detect the crop lines when placed in a field and navigate between them without destroying the plants. 
Next, it could detect fruits or crops with an intent to then harvest them by focusing on the shapes measured by a 3D depth sensor [3] or it could record the shape of the tree crown canopy [27] to adjust the dosage rate of pesticides based on the thickness of the tree crown. If there are no branches, the valves are shut, if there are the valves are open and if there are just a few, the valves are partly open.

It is useful to know the size of fruit or plants. If a fruit producer wants to make a prognosis about the yield of the harvest [24], he has to know the number and size of fruit. If a forester wants to estimate the biomass [4] of a tree it has to know its high and diameter or a volume. In all these cases having a 3D model of the scene would be useful and the system like this could be a part of an autonomous farming robot.

One of the most important parts of the software for such a robot would represent a SLAM (simultaneous localisation and mapping) algorithm. The most well-known SLAM algorithms are Gmapping [10,11] and Hector mapping [15]. To localize and create a map of the environment Gmapping relays on the use of Rao-Black wellized particle filter that minimizes the number of particles to reduce local uncertainty. The approach is optimised for long-range data captured by a LIDAR scanner and therefor suitable for large areas. But in order to work it needs additional data from the robots' odometry.

As tested in a previous work by [17], Hector mapping is not proven to be the best choice for outdoor environments due to changing conditions and unstructured pattern of the surrounding objects. Instead, an image analysis-based approach is suggested utilising image registration techniques done in the frequency domain. In comparison to Gmapping the presented approach works without any odometry data.

\section{CONCLUSION}

Technology, Artificial Intelligence (AI) and Machine Learning will change the game across the entire food system. On farms, AI and machine learning can deliver greater reliability in forecasting, such as weather conditions, pests and fluctuations in commodity prices. Cameras and applications can help detect illnesses, pathogens and weeds in a matter of seconds. Through a smart platform, the consumer can supply fresh and healthy food, and merchants can reduce the amount of discarded food. The consequences are improving general health, disease tracking, etc. Of course, we must be aware that achieving food security requires political and economic solutions to issues such as poverty and racial inequality. Innovation must reach the hands of those who need it the most - leaders must provide everyone with accessible, user-friendly and accessible technology. This must be our goal to which we strive. However, the paths that are going to the destination will, as always, be quite different.

\section{REFERENCES}

[1] Andujar, D., Rueda-Ayala, V., Moreno, H., Rosell, J. R., Escola, A., Valero, C., Gerhards, R., Griepentrog, H. W. 2013. Discriminating crop, weeds and soil surface with a terrestrial LIDAR sensor. Sensors 13 pp.14662-14675.

[2] Chaerle, L., Van Der Straeten, D. 2000. Imaging techniques and the early detection of plant stress. Trends in Plant Science 5, pp. 295-500. 
[3] Dzitac, P., Mazid, A. M. 2012. A depth sensor to control pick-and-place robots for fruit packaging, 12th International Conference on Control Automation Robotics \& Vision (ICARCV), pp. 949 - 954.

[4] Eler, K., Turk, B., Čop, J., Lazarevič, B., Vodnik, D. 2017. Multispektralni posnetki visoke prostorske ločljivosti v raziskavah v agronomiji - trije primeri uporabe. SAD, Novi izivi v agronomiji, Zbornik simpozija, Laško: 258-264.

[5] Garrido, M.; Paraforos, D. S.; Reiser, D.; Vazquez Arellano, M.; Griepentrog, H. W.; Valero, C. 2015. 3D Maize Plant Reconstruction Based on Georeferenced Overlapping LiDAR Point Clouds. Remote Sensing 7(12) 17077-17096.

[6] Germšek, B., Knapič, M. 2017. Uporaba brezpilotnih zrakoplovov v kmetijstvu. SAD, Novi izzivi v agronomiji, Zbornik simpozija, Laško: pp. 252-257.

[7] GNSS Geoservis. 2018. Retrieved on 18. October 2018 at: http://www.gnss.si/kako-deluje

[8] Gonzalez RC and Woods RE 2001. Digital image processing, 2nd edition, P.Hall, Upper Saddle River, New Jersey.

[9] GPS visualiser. 2018. Retrieved on 22. October at: http://www.gpsvisualizer.com

[10] Grisetti, G., Stachniss, C., Burgard, W. 2007. Improved Techniques for Grid Mapping with Rao-Blackwellized Particle Filters, IEEE Transactions in Robotics, Volume 23, pp. 34-46.

[11] Grisetti, G., Stachniss, C., Burgard, W.2005. Improving Grid-based SLAM with Rao Blackwellized Particle Filters by Adaptive Proposals and Selective Resampling, Proceedings of the IEEE Int.Conf. on Robotics and Automation.

[12] Hege, D. 2014. Retrieved on 11 September 2018 at: https://www.landwirtschaft.sachsen.de/landwirtschaft/6779.htm

[13] Jung, H., Lyou, J. 2014. 3D map building using the kinect mounted on a mobile robot, IEEE International Conference on Industrial Technology (ICIT), pp. $604-608$.

[14] Kašman, I. 2003. Diplomsko delo - Dokumentiranje in analiza stroškov delovnega postopka z uporabo satelitske navigacije. Univerza v Mariboru.

[15] Kohlbrecher, S., Meyer, J., Graber, T., Petersen, K., Klingauf, U., Stryk O. 2013. Hector Open Source Modules for Autonomous Mapping and Navigation with Rescue Robots, Dep. of Computer Science, TU Darmstadt, Germany.

[16] Landerl, G. 2009. Untersuchungen zum Nutzen und zu Genauigkeiten von GPS-gestützten Parallelfahrsystemen (Lenkhilfe, Lenkas- sistent und Lenkautomat) bei Traktoren. Wien, Universität für Bodenkultur.

[17]Lepej, P., Rakun, J. 2016. Simultaneous localization and mapping in a complex field environment, Biosystems Engineering, Volume 150, pp. 160-169.

[18]Lepej, P., Lakota, M., Rakun J. 2017. Robotic real-time 3D object reconstruction using multiple laser range finders. Advances in Animal Biosciences, Conference on Precision Agriculture (ECPA 2017), John McIntyre Centre, Edinburgh, UK, July, (8), 2: 16-20.

[19] Lopez, H. 2013. Retrieved on 25. October 2018., at: https://www.landwirtschaftskammer.de/duesse/rueckblick/pdf/2013-06-19-rentabilitaet-pf.pdf

[20] Ministrstvo za okolje in proctor. 2018. Retrieved on 26. October 2018 at: http://www.gusignal.si/node/1

[21] Pintar, M., Đurič, N., Nedog, M., Kastelec, D. 2017. Preliminarne meritve količine vode v tleh za potrebe interpretacije satelitskih slik. SAD, Novi izzivi v agronomiji, Zbornik simpozija, Laško: 189-195.

[22] Reckleben, Y. 2010. Vorzüge und Schwachstellen von Lenksystemen in der Landwirtschaft. Fachhochschule Kiel.

[23] Roh, H.C., Sung, C.H., Chung, M.J. 2013. Rapid SLAM using simple map representation in indoor environment, 19th Korea-Japan Joint Workshop on Frontiers of Computer Vision, pp. $225-229$. 
[24] Stajnko, D., Lakota, M., Hocevar, M. 2004. Estimation of number and diameter of apple fruits in an orchard during the growing season by thermal imaging. Computers and Electronics in Agriculture, 42, 31-42.

[25] Vajda, N., Kelc, D., Vindiš, P., Berk, P., Rakun, J., Stajnko, D., Lakota, M. 2018. Increase of soil tillage efficiency with using of RTK - navigation. $46^{\text {th }}$ International Symposium "Actual Tasks on Agricultural Engineering" $27^{\text {th }}$ February $-2^{\text {nd }}$ March 2018, Opatija, Croatia

[26] Vaukan, T. 2001. Diplomsko delo - Satelitska navigacija kot osnova za geoinformacijske sisteme v kmetijstvu. Univerza v Mariboru.

[27] Wellington, C., Campoy, J., Khot, L., Ehsani, R. 2012. Orchard tree modeling for advanced sprayer control and automatic tree inventory. In: Proc. IROS Workshop on Agricultural Robotics.

\section{AUTOMATIZACIJA I DIGITALIZACIJA U POLJOPRIVREDI}

\section{Miran Lakota, Denis Stajnko, Peter Vindiš, Peter Berk, Damijan Kelc, Jurij Rakun}

Univerzitet u Mariboru, Fakultet za poljoprivredu $i$ životne nauke, Pivola 10, 2311 Hoče, Republika Slovenija

Sažetak. Četvrta industrijska revolucija, koja je započela pre nekoliko godina, danas pokriva i "pametne" i međusobno povezane mašine i sisteme (u poljoprivredi) . Takođe se poklapa sa daljim otkrićima u različitim oblastima, od određivanja sekvenci genoma do nanotehnologije i iz obnovljivih izvora do kvantnog računarstva.

Korelacija između navedenih tehnologija i njihove interakcije u fizičkoj, digitalnoj i biološkoj oblasti čini ono što četvrtu industrijsku revoluciju znatno razlikuje od prethodnih.

Događaji bi trebali biti brži, opširniji i radikalniji, što zahteva transformaciju čitavih sistema kroz (i u okviru) pojedinih zemalja, biznisa, industrije i kompletnog društva.

Danas se već govori o prelasku sa finansiranja Inovativnih projekata (IP) na sveobuhvatne inovativne ekosisteme (AKIS).

Rad opisuje danas važne istraživačke radove iz oblasti automatizacije i digitalizacije poljoprivrede u Republici Sloveniji.

Ključne reči: precizno farmerstvo, pametna poljoprivreda, roboti u poljoprivredi.
Prijavljen:
Submitted:
10.03.2019.
Ispravljen:
Revised:
08.04.2019.
Prihvaćen:
Accepted:
10.04.2019. 